\title{
Serum Copper Elevation from Estrogen Effect, Masquerading as Fungicide Toxicity
}

\author{
Alan Buchwald, MD
}

Department of Emergency Medicine, Dominican Hospital/Catholic Healthcare West

\begin{abstract}
Introduction: Copper toxicity has previously been reported from the wood preservative, copper naphthenate. Serum copper levels may be elevated by estrogen. Reported here is a case of a woman who was initially diagnosed with elevated serum copper levels from copper naphthenate exposure. She was later found to have a normal RBC copper level with resolution of her elevated serum copper level following discontinuation of estrogen.

Case Report: A previously healthy 44-year-old Caucasian female was referred for toxicology consultation due to persistently elevated serum copper levels following copper naphthenate applied in her home. She had initial nausea, nasal congestion and headache from the fumes but then remained asymptomatic. No evidence of underlying systemic disease or organ injury was found. Despite this and no further exposure, her serum copper remained elevated by $30 \%$ above normal over 9 months, peaking at $2301 \mu \mathrm{g} / \mathrm{L}$ ( $36 \mu \mathrm{mol} / \mathrm{L}$ ). Review of the literature confirmed that oral contraceptive use will routinely elevate serum copper levels to the extent noted in this case. Her RBC copper level was normal. Cessation of the oral contraceptive for 2 months returned the serum copper levels to normal.

Discussion: This patient's elevations in serum copper were probably unrelated to her chemical exposure to copper naphthenate. Serum levels of copper were falsely elevated as a result of concomitant estrogen use, and were returned to normal when estrogen was discontinued.
\end{abstract}

\section{INTRODUCTION}

Copper naphthenate (CAS\# 1338-02-9) is a fungicide used as a wood preservative. Very few cases of toxicity have been reported in the literature. In this case, persistently elevated serum copper levels were thought to be due to a woman's exposure to the fumes of copper naphthenate. She remained asymptomatic without end organ injury, and serum copper levels were later shown to be due to the physiologic effect of her oral contraceptive. This case also shows the value of RBC copper levels in assessing copper toxicity risk.

\section{CASE REPORT}

A previously healthy 44-year-old Caucasian female was exposed to fumes from copper naphthenate applied to wood beams in her home bathroom by a termite removal contractor. This was in the form of a wood preservative, comprised of $15 \%$ copper naphthenate, $50 \%$ process oil, and $35 \%$ mineral spirits. In spite of attempts to ventilate the material out the bathroom window with a fan, the patient still noted a strong turpentine-type odor throughout the home. She indicated that the container label recommended outside use only. She noted nausea, nasal congestion, and headache, but no associated cough, runny nose, or eye irritation. Her husband had no symptoms, but he slept further from the bathroom area than his wife; they had no children or pets.

She was seen in the local emergency department; no significant clinical findings were noted and no tests were done. The poison control center was consulted. Avoidance and ventilation of the home was recommended. The odor in the home persisted, and a "wood remediation" sealant was applied. Subsequently, the odor dissipated over 3 weeks. Five weeks after the initial exposure,

Keywords: copper naphthenate, RBC copper, fungicide

Notes: There was no outside funding of any kind used for this study. Corresponding Author: Alan Buchwald, MD, P.O. Box 2289, Aptos, Ca. 95001. Phone and Fax: 831-761-0260. Email: albuchwald955@pol.net 
the patient saw her primary doctor; at that time she was asymptomatic, but serum copper was elevated to $1500 \mu \mathrm{g} / \mathrm{L}(24 \mu \mathrm{mol} / \mathrm{L})$ (normal $800-1300 \mu \mathrm{g} / \mathrm{L}$, performed by a certified laboratory, analysis by flame atomic absorption spectroscopy).

A heavy metal blood panel was obtained with normal values (arsenic $<10 \mu \mathrm{g} / \mathrm{L}$, mercury $<4 \mu \mathrm{g} / \mathrm{L}$, lead $<3 \mu \mathrm{g} / \mathrm{dL}$ ). These tests were repeated and were normal 1 month later, but serum copper remained elevated at $2055 \mu \mathrm{g} / \mathrm{L}(32 \mu \mathrm{mol} / \mathrm{L}$ ) (normal 490-1840 $\mu \mathrm{g} / \mathrm{L})$, performed by another certified laboratory, analysis by flame atomic absorption spectroscopy). She remained asymptomatic at 6 months post-exposure, but serum copper was still elevated at $2301 \mu \mathrm{g} / \mathrm{L}(36 \mu \mathrm{mol} / \mathrm{L})$ (normal 490-1840 $\mu \mathrm{g} / \mathrm{L})$.

A comprehensive metabolic panel was obtained and was normal, including liver function testing. An industrial medicine specialist saw her at 7 months. CBC and comprehensive panel were normal, but serum copper remained elevated at $2003 \mu \mathrm{g} / \mathrm{L}$ (36 $\mu \mathrm{mol} / \mathrm{L})$ (normal 490-1840 $\mu \mathrm{g} / \mathrm{L}$ ). Toxicology consultation was recommended.

The patient was seen in consultation by this author, a boardcertified medical toxicologist, at 9 months post-exposure. She remained asymptomatic, was living in the same home, and had no other significant changes since the exposure. Her husband had never been ill, but lab testing on him at 1 and 2 months post-exposure was said to be normal (documents not available to the author). There was no other significant exposure for copper. Water pipes in the home were thought to be copper, but the patient drank commercial bottled water. Medications included: Wellbutrin $150 \mathrm{mg} /$ day, Omega 3 fatty acid, Flaxseed, and Yasmin (drospirenone and ethinyl estradiol) oral contraceptive. She was taking no vitamins and had not used a copper IUD, copper bracelets or copper-based ointments. Past medical history was remarkable for prior shoulder rotator cuff surgery, bilateral foot surgery, and sinus surgery. There was a history of hay fever to pollen and mold, with sporadic sinus headaches. She used occasional alcohol, but did not smoke or use street drugs. Review of systems was unremarkable. She rarely used insecticides in the garden, but no copper agents. Family and social history were noncontributory. She was an administrative analyst at a university with no chemical exposure. Physical exam was unremarkable, including no Kayser-Fleischer rings in the cornea. CBC, comprehensive panel, serum iron studies, sedimentation rate, CRP, TSH, rheumatoid factor and ANA were normal. Serum copper was 1930 $\mu \mathrm{g} / \mathrm{L}(30 \mu \mathrm{mol} / \mathrm{L})$ (normal 800-1550 $\mu \mathrm{g} / \mathrm{L}$, performed by third certified laboratory, analysis by inductively coupled plasma/mass spectrometry); ceruloplasmin was $49 \mathrm{mg} / \mathrm{dL}$ (normal 17-54).

Subsequently, RBC copper was obtained and was normal at $0.65 \mathrm{mg} / \mathrm{L}(10 \mu \mathrm{mol} / \mathrm{L})$ (normal range $0.53-0.77 \mathrm{mg} / \mathrm{L})$ and a $24-$ hour urine copper was $2.3 \mu \mathrm{g} / \mathrm{dL}(0.36 \mu \mathrm{mol} / \mathrm{L}$ ) (normal 0.2-8.0 $\mu \mathrm{g} / \mathrm{dL})$; simultaneous serum copper remained elevated at 2284 $\mu \mathrm{g} / \mathrm{L}(36 \mu \mathrm{mol} / \mathrm{L})$ (normal 490-1840 $\mu \mathrm{g} / \mathrm{L})$.

A low copper diet was instituted; chelation was not recommended. Subsequently, on further literature review an estrogen effect was suspected and the low copper diet was discontinued. The patient agreed to stop her oral contraceptive for 2 months and repeat lab tests. Subsequently, 11 months post-exposure, serum copper was normal at $1331 \mu \mathrm{g} / \mathrm{L}(21 \mu \mathrm{mol} / \mathrm{L})$ (normal $490-1840 \mu \mathrm{g} / \mathrm{L})$, with an RBC copper of $0.49 \mathrm{mg} / \mathrm{L}(7.7 \mu \mathrm{mol} / \mathrm{L})$ (normal $0.53-0.77 \mathrm{mg} / \mathrm{L}$ ). The serum copper level represented a $30 \%$ reduction from prior levels; the slightly low RBC copper result was not thought to be significant. Hormone levels were not obtained.

\section{DISCUSSION}

Copper toxicity from copper naphthenate has previously been reported in the literature, but is rare. The first case was reported in 1992 in a family of three (all women, ages 18, 21, and 44 years) where copper naphthenate was sprayed on the inner foundation of a home.

They reported nausea, vomiting, burning of the eyes, dizziness, and headache. Two of the individuals had elevated serum copper levels; one (the mother) was followed over several years and had gradual decline in serum and urine copper levels. For example, serum levels declined from $2250 \mu \mathrm{g} / \mathrm{L}(35 \mu \mathrm{mol} / \mathrm{L})$ at 14 months post-exposure to $1800 \mu \mathrm{g} / \mathrm{L}(28 \mu \mathrm{mol} / \mathrm{L})$ at 41 months (normal 750-1450 $\mu \mathrm{g} / \mathrm{L}$ ). It was not known if "symptoms reflected exposure to naphthenate, the solvent vehicle, volatized copper, or the stress of the exposure to a malodorous compound perceived as toxic." It was noted that volatility of the chemical was moderately low, although no air levels were ever measured. Chelation therapy was not performed. RBC copper levels were not done and medications were not listed. As noted in the article, "The interpretation of copper levels regarded as 'normal' or 'toxic' after copper naphthenate exposure is, however, uncertain and requires additional study for clarification." [1] A 1999 abstract from the San Francisco poison center reported on a case of elevated serum copper and methemoglobinemia from residential exposure to copper naphthenate. A family of five (41-year-old male, 40-year-old female and three children aged 2, 3, and 5 years) was exposed to copper naphthenate sprayed heavily on the hardwood floor of their home. Symptoms included headache, dizziness, nausea and fatigue. An initial methemoglobin level was $16 \%$ in the mother; following ventilation and shutting off the heater it was $0.9 \%$ at 12 days. Serum copper levels were reported as $1000 \mu \mathrm{g} / \mathrm{L}(16 \mu \mathrm{mol} / \mathrm{L})$ in the father, $1450 \mu \mathrm{g} / \mathrm{L}(23 \mu \mathrm{mol} / \mathrm{L})$ in the mother; $1650(26 \mu \mathrm{mol} / \mathrm{L})$ in the 5-year-old, $2000(31$ $\mu \mathrm{mol} / \mathrm{L})$ in the 3-year-old, and $2200(35 \mu \mathrm{mol} / \mathrm{L})$ in the 2 -year-old (normal 650-1450 $\mu \mathrm{g} / \mathrm{L}$ ).

No RBC copper levels were reported, nor was medication use. The family moved out of the house, but no repeat levels were done [2]. Elevations in serum copper have been reported in various anemias, including iron deficiency, leukemia, infection, lymphoma, biliary cirrhosis, hemochromatosis, collagen diseases, thyroid disorders, pregnancy and ingestion of oral contraceptives/estrogens, and Wilson's disease [3]. Hinks reported on copper concentrations in leukocytes and erythrocytes and the effect of estrogens in 1983 [4]. Whole blood was obtained from 119 normal healthy volunteers: 55 men aged 18-63 years and 64 
women aged 21-57 years. Twenty-two of the women were taking a combination oral contraceptive ("the pill," ethinyloestradiol $30 \mu \mathrm{g}$ and levonorgestrel $150 \mu \mathrm{g}$ ). No hormone levels were reported.

Reference ranges for copper were derived from cumulative frequency distribution curves. Plasma copper reference range varied from $12.5-21.0 \mu \mathrm{mol} / \mathrm{L}$ for women off the pill to $15.5-29.5$ on the pill (where $\mu \mathrm{mol} / \mathrm{L} \times 63.5=\mu \mathrm{g} / \mathrm{L}$ ). Measured plasma copper for women off the pill averaged $16.7 \pm 2.8 \mu \mathrm{mol} / \mathrm{L}$, while those on the pill averaged $24.3 \pm 3.7 \mu \mathrm{mol} / \mathrm{L}$. RBC copper for those off the pill was $1.11 \pm 0.16$ picamol $/ 10^{6}$ cells and for those on the pill $1.17 \pm 0.21$ picamol $/ 10^{6}$ cells. Thus, significant increases in plasma copper concentrations were noted in women taking oral contraceptives "and these findings are consistent with previous reports." It was thought that the increase was a result of increased synthesis of ceruloplasmin in response to estrogen, but the metabolic balance of copper was not altered. "It was noted that no significant increase was found in the copper content of leucocytes or erythrocytes in the group of women taking oral contraceptives." Hinks also noted: "The analysis of leucocytes may reflect more accurately acute changes in zinc and copper status as these are metabolically active and have a shorter life span than erythrocytes, and because they (unlike erythrocytes) are nucleated, they are more likely to be representative of other cells. Additionally, Baselt has noted: "In a study of 48 cases of acute (usually intentional) copper sulfate poisoning, it was found that blood \{presumed RBC\} copper levels correlated well with the severity of intoxication, whereas serum levels did not" [5].

Also, Goodhart noted that serum copper is increased in a number of conditions (vide supra), but "In general the concentration in red blood cells is unaffected" [6]. According to the Expert Group on Vitamins and Minerals: "Acute copper toxicity in humans is rare due to the emetic properties and unpleasant taste of the compounds. There are relatively few data on lower level or chronic oral copper exposure in man. Copper is kept under tight homeostatic control to prevent the accumulation of excess amounts.

Where dietary copper is high, absorption is reduced and, in particular, biliary excretion is increased. Other mechanisms, which sequester excess copper within the cell, may also occur. Copper toxicity occurs when such defenses are overwhelmed. Thus, in man, liver toxicity has only been seen in genetically determined conditions such as Wilson's disease and in Indian Childhood Cirrhosis where hepatic copper accumulation occurs." [7]

In this case, there was no clear evidence of any of the underlying disease processes associated with elevated serum copper levels. Additionally, except for a brief period following her exposure to the copper naphthenate fumes, she had no symptoms or evidence of end organ injury once her exposure ceased. The persistent elevation of serum copper months after the initial exposure suggested a non-toxic or laboratory effect, which was most consistent with the effect seen with estrogen intake. Removal of exogenous estrogen resulted in a normalization of the serum copper, without a significant effect on RBC copper (although it was slightly lower than normal). In retrospect, the estrogen effect on serum copper resulted in about a 30\% increase from the patient's normal range. It is not known if this would be comparable for other women taking exogenous estrogen, although this was approximately the same range of increase seen in the cases reported by Hinks.

\section{CONCLUSION}

Although exposure to copper naphthenate has the potential to raise serum levels of copper, it is not known if RBC copper levels would be affected, as no cases until now have ever been tested. At least in this case, such an exposure led to repeated measurements of serum copper in an asymptomatic patient, later shown to be due to exogenous ingestion of estrogen for birth control as a normal physiologic effect. Copper naphthenate toxicity would appear to be an unlikely event in this case. This case reaffirms the importance of thorough history taking and evaluating all potential sources of elevated serum copper levels. Toxicologists should consider measurement of RBC copper levels as a better indicator of toxicity risk when faced with clinical exposures to excess copper.

\section{REFERENCES}

1. Bluhm R, Welch L, Branch R. Increased blood and urine copper after residential exposure to copper naphthenate. Clin Toxicol 1992;30(1): 99-108.

2. Kim S, Chomchai S. Elevated serum copper levels and methemoglobinemia from residential exposure to copper naphthenate. J Toxicol/Clin Toxicol 1999;37(5):622.

3. Wallach J, editor. Interpretation of Diagnostic Tests. 7th ed. Philadelphia: Lippincott Williams \& Wilkins; 2000.

4. Hinks LJ, Clayton BE, Lloyd RS. Zinc and copper concentrations in leucocytes and erythrocytes in healthy adults and the effect of oral contraceptives. J Clin Path 1983;36:1016-1021.

5. Baselt RC, editor. Disposition of Toxic Drugs and Chemicals in Man. 7th ed. Foster City, CA: Chemical Toxicology Institute; 2004.

6. Goodhart RS, Shils ME, editors. Modern Nutrition in Health and Disease. 6th ed. Philadelphia: Lea \& Febiger; 1980.

7. Langman, $\mathrm{M}$ et al. Expert Group on Vitamins and Minerals, Food Standards Agency, EU, 2003. 